\title{
DNA Polymerase $\varepsilon$ - More Than a Polymerase
}

\author{
Helmut Pospiech ${ }^{1}$ and Juhani E. Syväoja ${ }^{1,2,{ }^{*}}$ \\ ${ }^{1}$ Biocenter Oulu and Department of Biochemistry, P.O. Box 3000, FIN-90014 University \\ of Oulu, Finland; ' ${ }^{2}$ Department of Biology, University of Joensuu, P.O. Box 111, FIN- \\ 80101 Joensuu, Finland \\ E-mail: Juhani.Syvaoja@oulu.fi
}

Received June 3, 2002; Revised June 27, 2002; Accepted June 28, 2002; Published March 24, 2003

This paper presents a comprehensive review of the structure and function of DNA polymerase $\varepsilon$. Together with DNA polymerases $\alpha$ and $\delta$, this enzyme replicates the nuclear DNA in the eukaryotic cell. During this process, DNA polymerase a lays down RNA-DNA primers that are utilized by DNA polymerases $\delta$ and $\varepsilon$ for the bulk DNA synthesis. Attempts have been made to assign these two enzymes specifically to the synthesis of the leading and the lagging strand. Alternatively, the two DNA polymerases may be needed to replicate distinct regions depending on chromatin structure. Surprisingly, the essential function of DNA polymerase $\varepsilon$ does not depend on its catalytic activity, but resides in the nonenzymatic carboxyterminal domain. This domain not only mediates the interaction of the catalytic subunit with the three smaller regulatory subunits, but also links the replication machinery to the S phase checkpoint.

In addition to its role in DNA replication, DNA polymerase $\varepsilon$ fulfils roles in the DNA synthesis step of nucleotide excision and base excision repair, and has been implicated in recombinational processes in the cell.

KEY WORDS: DNA polymerase epsilon, DNA replication, DNA repair, checkpoint, DNA damage response, chromatin

DOMAINS: biochemistry, cell cycle, cell biology, enzymology and protein-protein interaction, genetics (yeast)

\section{DISCOVERY AND STRUCTURE OF POL $\varepsilon$}

DNA polymerase (Pol) $\varepsilon$ was first isolated as a nuclear Pol from yeast as early as 1970[1]. Soon after, the corresponding Pol was purified from rabbit bone marrow as an enzyme associated with $3^{\prime} \rightarrow 5^{\prime}$ exonuclease activity[2]. It has been isolated and characterised from several mammalian sources as an enzyme with varying molecular weights, $170 \mathrm{kDa}$ from human placenta[3], 260 $\mathrm{kDa}$ from HeLa cells[4,5,6], and $140 \mathrm{kDa}$ from calf thymus[7,8]. At least for calf thymus Pol $\varepsilon$, it *Corresponding author. 
was shown that the $140-\mathrm{kDa}$ form represents a proteolytic fragment, and that a similar fragment can be formed specifically during apoptosis by caspase-3 and calpain[9,10]. Pol $\varepsilon$ was initially considered to be a form of Pol $\delta$ that was processive in the absence of PCNA and RFC at low ionic strength[11]. Later Pol $\varepsilon$ was shown to be an independent Pol and the catalytic subunit was isolated and cloned from several species[12,13,14,15,16,17,18,19,20].

Pol $\varepsilon$ is a member of the B family of Pols[21,22] that includes the two other replicative Pols, $\alpha$ and $\delta$. The structure of Pol $\varepsilon$ is typical of this family, but notably, the catalytic subunit possesses a large C-terminal domain of unclear function that accounts for half of the molecular weight of $\sim 260 \mathrm{kDa}[23]$. This domain is located between the Pol domain and the putative zincfinger.

Detailed phylogenetic analyses indicate that $\mathrm{Pol} \varepsilon$ is the orthologue to the archaeal Pol BI rather than to Pols $\alpha, \delta$, or $\zeta[24,25]$. Therefore, a gene duplication event of the ancestral family B Pol gene must have occurred early in evolution prior to the separation of the eukaryotic and archaeal lineages[24]. Pol B1 is found ubiquitously in Archaea and, like the eukaryotic Pols of family $\mathrm{B}$, is inhibited by aphidicolin[24,26,27]. The phylogenetic affiliation of Pol $\varepsilon$ with the archaeal Pols is also reflected by several similarities in the primary sequence of these enzymes[23]. Whereas the five typical motifs of the exonuclease domain are well conserved in Pol $\varepsilon[28,29,30]$, several changes in seven conserved motifs that characterise the Pol domain are distinct in Pol $\varepsilon$ compared to other family B Pols[23,31,32,33]. The changes mainly concern residues that have been implicated in template-primer binding and stabilisation of the newly incoming nucleotide, arguing for a catalytic centre architecture that is distinct from other Pols of family B.

Apart from the large catalytic subunit, Pol $\varepsilon$ contains three more subunits that differ in size but are conserved in their primary structure from yeast to human (Table 1, Fig. 1, [34]). The second largest, subunit B, has been cloned from several species[35,36,37]. Like the catalytic subunit[13,18,19], the B subunit is also essential for viability in yeast[35]. The DPB3 and DPB4 genes encode the two smallest, nonessential subunits of budding yeast Pol $\varepsilon[38,39]$. The fourth subunit p17 of the human Pol $\varepsilon$, homologous to DPB4, has been cloned, and the probable DPB3 homologue $\mathrm{p} 12$ has been identified by homology searches[40]. Initially, a subunit stoichiometry of 1:1:4:4 has been proposed for purified as well as reconstituted recombinant yeast Pol $\varepsilon[41,42]$. A recent, detailed analysis of the properties of native yeast Pol $\varepsilon$ indicates that the enzyme is rather a heterotetramer with a stoichiometry of 1:1:1:1[43].

\section{STRUCTURE AND FUNCTION OF THE B SUBUNIT}

Despite their variable size of $59-86 \mathrm{kDa}$, the Pol $\varepsilon$ B subunits are homologous in primary structure[35,36,37]. More detailed analysis of the human B subunit revealed further similarities to B subunits of the eukaryotic Pols $\alpha$ and $\delta$, as well as to the small subunit of the archaeal Pol DI (Pol II)[44]. Twelve conserved motifs cover most of the primary structure of the B subunits and define a protein superfamily (Fig. 2). It is particularly intriguing that the catalytic subunit associated with eukaryotic B subunits belong to the Pol family B, whereas the catalytic subunit associated with archaeal B subunits belong to family D. Enzymes of this Pol family have so far only been identified in the kingdom Euryarchaeota, and they do not share sequence homology to other Pol families $[27,45,46]$. The conservation of the B subunits of different Pols argues not only for a similar fold, but also for a conserved function shared by these subunits. All Pols with conserved B subunits are implicated in DNA replication[34,48] and they are all essential for cell viability[49]. Genetic and biochemical studies indicate that the putative zinc finger regions in the catalytic subunit of Pols $\delta$ and $\varepsilon$ are important for the interaction with the B subunits[47,50,51]. 
TABLE 1

Subunit Designation of Pol $\varepsilon$ from Different Species

\begin{tabular}{|c|c|c|c|c|}
\hline $\begin{array}{c}\text { Subunit } \\
\text { Designation }\end{array}$ & Human & S. cerevisiae & S. pombe & Comments \\
\hline A & $\begin{array}{c}\text { p261 (POLE) } \\
(262)^{1}\end{array}$ & $\begin{array}{l}\text { POL2 } \\
(256)\end{array}$ & $\begin{array}{l}\operatorname{cdc}^{+} \\
(253)\end{array}$ & $\begin{array}{l}\text { Catalytic subunit; } \\
\text { DNA polymerase and } \\
\text { proofreading exonuclease }\end{array}$ \\
\hline B & $\begin{array}{c}\text { p59 (POLE2) } \\
(60)\end{array}$ & $\begin{array}{c}\text { DPB2 } \\
(79)\end{array}$ & $\begin{array}{c}\text { dpb2 }^{+} \text {(SPBP8B7.14c) }^{2} \\
(67)\end{array}$ & $\begin{array}{l}\text { Interacts with subunits A; } \\
\text { forms a dimer; potential OB- } \\
\text { fold and phosphoesterase-like } \\
\text { domains }\end{array}$ \\
\hline C & $\begin{array}{l}\mathbf{p} 12^{2} \\
(12)\end{array}$ & $\begin{array}{l}\text { DPB3 } \\
(23)\end{array}$ & $\begin{array}{c}\text { SPAC } 17 G 8.03 c ?^{2,3} \\
(22)\end{array}$ & $\begin{array}{l}\text { Interacts with subunits A and } \\
\text { D; histone-fold }\end{array}$ \\
\hline D & $\begin{array}{l}\text { p17 (POLE3; } \\
\text { CHRAC17) } \\
(17)\end{array}$ & $\begin{array}{l}\text { DPB4 } \\
(22)\end{array}$ & $\begin{array}{c}\mathrm{dpb}^{+}(\text {(SPBC3D6.09) })^{2} \\
(24)\end{array}$ & $\begin{array}{l}\text { Interacts with subunits A and } \\
\text { C; subunit of chromatin } \\
\text { remodeling complex CHRAC; } \\
\text { histone-fold }\end{array}$ \\
\hline
\end{tabular}

1The predicted molecular weight in $\mathrm{kDa}$ is indicated in brackets.

2Assignment based on sequence homology.

3The DPB3 homologue of S. pombe cannot be assigned unambitiously by sequence homology.

No catalytic function has been assigned to the Pol $\varepsilon$ B subunit or other members of the family. Nevertheless, a calcineurin-like phosphoesterase domain spanning the C-terminal half of the protein has been identified[52,53,54,55], as well as an $\mathrm{OB}$ (oligonucleotide/oligosaccharide binding)-fold domain in archaeal B subunits[56,57] (Fig. 2). The OB-fold and the calcineurin-like domain are separated by a short proline-rich region[44]. The OB-fold suggests that nucleic acid binding may be a common feature of Pol B subunits.

The presence of a calcineurin-like domain suggests that an enzymatic activity was originally intrinsic to B subunits that has been lost in Pol $\varepsilon$ and other eukaryotic B subunits[52,53,54,55]. The B subunits may therefore represent an ancient proofreading exonuclease that is still present in the Pol family D[58].

The Pol $\varepsilon$ B subunit has been implicated in protein-protein interactions. It mediates homodimerisation of the enzyme and interacts with the C-terminal part of the catalytic subunit as well as with the two small subunits[51].

Recently, the mouse Pol $\varepsilon$ B subunit was found to interact with SAP18, which is known to associate with the transcriptional corepressor Sin3[59] (Fig. 1). Sin3 is a component of a protein complex possessing histone deacetylase activity that interacts with several transcriptional corepressors and functions in transcriptional silencing[60]. Recruitment of the B subunit/Sin3 complex to DNA resulted in transcriptional repression in a model system. The effect depended at least in part on the histone deacetylase activity[59]. It has been proposed that $\operatorname{Sin} 3$ is involved in the establishment of growth arrest by repressing transcription from E2F-dependent promoters and possibly alters chromatin structure at DNA replication origins[61]. These observations can be linked to the unpacking and repacking of chromatin during DNA replication or its initiation. On the other hand, the interaction with the histone deacetylase complex could also be important for 
the regulation of Pol $\varepsilon$ function itself due to potential covalent modification of the two smallest subunits that possess a histone fold (see below).

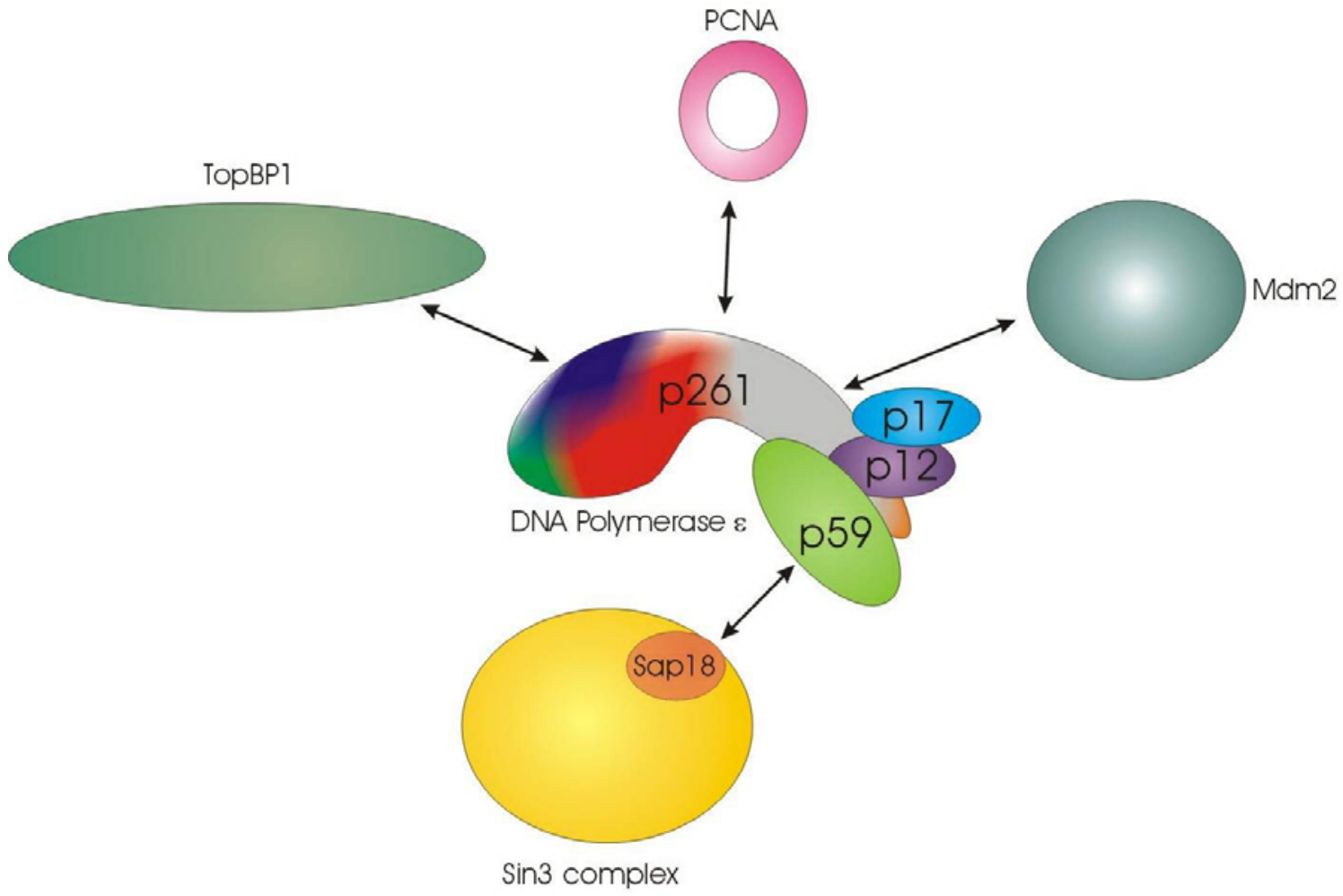

FIGURE 1. Subunit structure of human Pol $\varepsilon$, and the reported interactions with other proteins. The aminoterminal, exonuclease, and polymerase domains, and the carboxyterminal zinc fingers of the catalytic subunit are indicated schematically in green, blue, red, and orange, respectively.

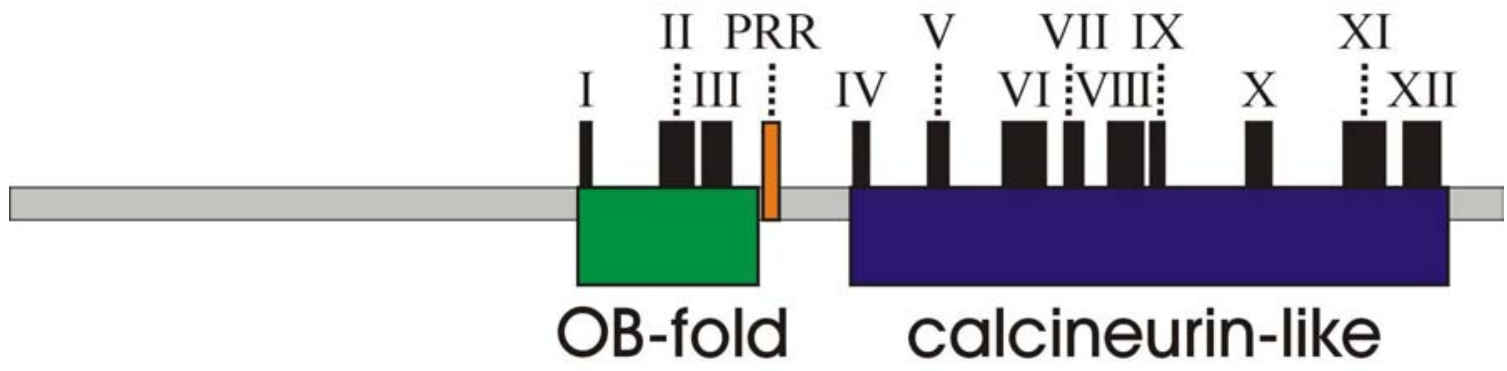

FIGURE 2. General structure of the Pol-associated B subunits. The location of the conserved motifs is indicated on top and marked with Roman numerals. PRR designates the proline-rich region between motifs III and IV. Below, the domain architecture of the B subunits is depicted.

In the budding yeast Saccharomyces cerevisiae, Pol $\varepsilon$ has a role in the silencing of ribosomal DNA at the mating type locus, as is also the case for Pol $\alpha$ and several other replication factors $[62,63]$. The silenced DNA is characterised by a low content of histone acetyl groups. The underlying mechanisms that link replication factors to transcriptional silencing are not yet understood, and although silencing requires transition through the $\mathrm{S}$ phase of the cell cycle, the process is not dependent on DNA replication itself[64,65]. Clearly, very little is known of the details that link Pol $\varepsilon$ to transcriptional regulation. 


\section{THE TWO SMALLEST SUBUNITS OF POL $\varepsilon$ - THE CHROMATIN CONNECTION}

The two smallest subunits of Pol $\varepsilon$ possess a histone-fold of the $\mathrm{H} 2 \mathrm{~A} / \mathrm{H} 2 \mathrm{~B}$ type and are closely related to the histone-fold subunits of the CCAAT binding factor[39,40]. They form a stable dimer that interacts with the other two larger subunits[40,51]. The behaviour of the smaller subunits on SDS polyacrylamide gels suggests a posttranslational modification. In particular, the yeast $\mathrm{Dpb3p}$ with a calculated molecular weight of $23 \mathrm{kDa}$, migrates as two discrete bands of 31 and $34 \mathrm{kDa}$. Apart from phosphorylation, the subunits could be subject to acetylation and methylation that are typical for histone-like proteins.

Interestingly, p17 has been independently identified as an integral subunit of the chromatinremodelling factor CHRAC[66]. CHRAC is an ISWI containing complex identified in different species that regulates chromatin accessibility and nucleosome spacing[66,67]. In CHRAC, Pol $\varepsilon$ p17 forms a dimer with a protein closely related to the Pol $\varepsilon$ p12 subunit that can interact with histones and DNA[68]. Such a homologue of $D P B 3$ was also identified in yeast[69].

\section{INTERACTION OF POL $\varepsilon$ AND PCNA}

The functional interaction between Pol $\varepsilon$ and PCNA has been the subject of a detailed study. Like Pol $\delta$, Pol $\varepsilon$ forms a highly processive holoenzyme complex with replication factors RFC and PCNA under physiological conditions[6,70,71]. The interaction of Pol $\varepsilon$ with PCNA apparently serves a dual role in stimulating the activity of the enzyme. PCNA facilitates binding of the primer end and prevents unproductive binding of single-stranded DNA[71,72,73]. On the other hand, PCNA stimulates the activity of the enzyme itself. The interaction sites of PCNA for Pol $\varepsilon$ have been mapped in detail by mutational analysis of PCNA. While for Pol $\delta$, the interaction with the interdomain loop of PCNA appears to be most important, Pol $\varepsilon$ interacts with the front side of PCNA including its very C-terminus[74,75,76]. A second interaction with the back is important for PCNA stimulation of the primer binding by Pol $\varepsilon[76]$. The PCNA interaction sites of Pol $\varepsilon$ are not so well characterised. A near-consensus PCNA-interacting protein (PIP) site[77] has been identified in the primary structure of the catalytic subunit adjacent to the Pol domain[42,78] (Fig. 1). A peptide corresponding to this motif in human Pol $\varepsilon$ is able to bind PCNA, albeit with low efficiency (A. Rytkönen, J. Tuusa, and J.E. Syväoja, unpublished observation). Mutation of the motif in budding yeast did not affect cell viability, but rendered the cells sensitive to methyl methanesulphonate. This suggests that the region is actually involved in the interaction with PCNA. Supportive evidence again comes from the related archaeal Pols of family B. Many of these possess a related PIP motif at the same position as in Pol $\varepsilon$, adjacent to the conserved motif C-3[23,79] (Fig. 3). This site is located in the very C-terminus of the archaeal Pols. Archaeal Pols have been shown to bind PCNA, resulting in increased activity due to higher processivity[79,80,81]. Despite the functional interaction with PCNA, one should bear in mind that Pol $\varepsilon$ retains considerable activity and processivity even in the absence of PCNA under various reaction conditions[5,82]. This is a fundamental difference from $\mathrm{Pol} \delta$ and it is possible that Pol $\varepsilon$ performs limited DNA synthesis in the absence of PCNA in the cellular context[72]. 


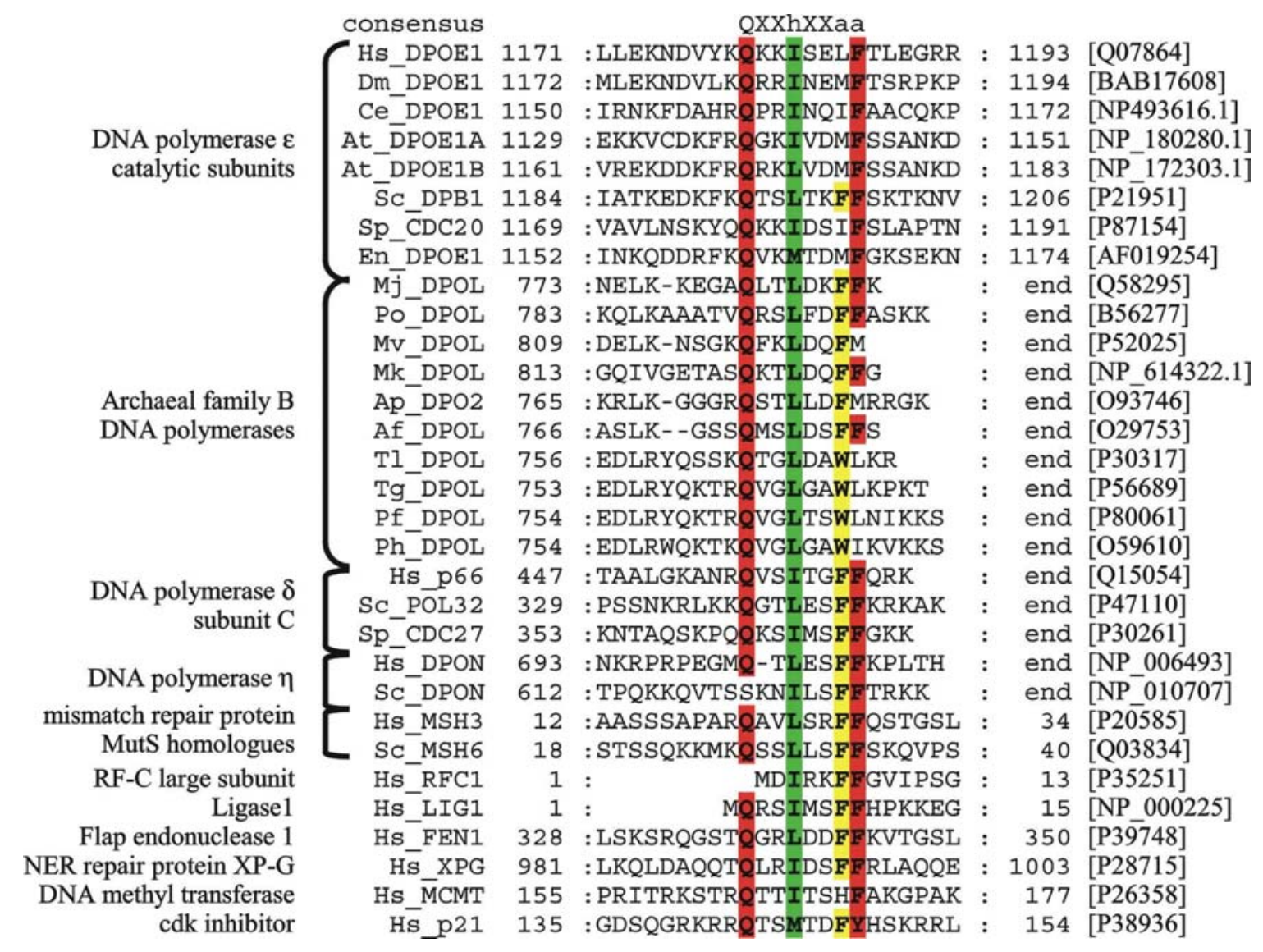

FIGURE 3. A conserved PCNA interaction site among Pol $\varepsilon$ and archaeal Pols of family B. The conserved PCNA-interacting sites of Pol $\varepsilon$, archaeal Pols of family B, Pol $\delta$ subunit C, Pol $\eta$, as well as representative replication and cell cycle regulating proteins are aligned. Species abbreviations are Hs - Homo sapiens; Dm - Drosophila melanogaster; Ce - Caenorhabditis elegans; At Arabidopsis thaliana; Sc - Saccharomyces cerevisiae; Sp - Schizosaccharomyces pombe; En - Emericella nidulans; $\mathrm{Mj}-$ Methanococcus jannaschii; Po - Pyrodictium occultum; Mv - Methanococcus voltae; Mk - Methanopyrus kandleri; Ap - Aeropyrum pernix; Af - Archaeoglobus fulgidus; $\mathrm{Tl}$ - Thermococcus litoralis; Tg - T. gorgonarius; $\mathrm{Pf}$ - Pyrococcus furiosus; $\mathrm{Ph}-\mathrm{P}$. horikoshii. Genbank accession numbers are indicated next to each sequence.

\section{POL $\varepsilon$ IS INVOLVED IN REPLICATION OF CELLULAR DNA}

The introduction of Simian Virus 40 (SV40) DNA replication as a model for mammalian DNA replication by Thomas Kelly and coworkers[83] allowed the rapid identification and characterisation of cellular factors involved in replication. The SV40 replisome can be considered the prototypic core replication apparatus in the eukaryotic cell, with the exception that the viral large $\mathrm{T}$ antigen serves both as initiator and as replicative DNA helicase[84]. Pols $\alpha$ and $\delta$ are involved both in leading and lagging strand DNA synthesis in the SV40 DNA replication system reconstituted with purified proteins[85,86,87]. The switch from Pol $\alpha$ to Pol $\delta$ occurs after initiation of the leading strand as well as after priming of each Okazaki fragment on the lagging strand with the primase of the Pol $\alpha$-primase complex[88,89,90]. Pol $\varepsilon$ is not required in this system[6,89,90,91,92].

The validity of the SV40 DNA replication system as a model of cellular DNA replication is challenged by research done with cellular systems. The catalytic subunit of Pol $\varepsilon$ is essential for viability in budding and fission yeast, and temperature-sensitive mutants fail to replicate chromosomal DNA at the restrictive temperature[13,18,19,93,94]. It is rather surprising though, that in fact the carboxy-terminal domain is sufficient for cell viability, whereas the Pol and 
exonuclease domains are dispensable[95,96,97]. The putative zinc fingers appear to be particularly important, since several mutants in this domain or the adjacent C-terminus have growth defects[50,94]. The results could be explained if the Pol $\varepsilon$ carboxy-terminal domain is required for the assembly of the cellular replication apparatus while the catalytic domains are not essential for replication, or possibly the catalytic function of Pol $\varepsilon$ could be replaced by other Pols, most likely by Pol $\delta$. Nevertheless, another Pol activity cannot fully substitute Pol $\varepsilon$, since the deletion of the N-terminal portion of the enzyme causes temperature sensitive phenotype in a certain strain background, abnormal S phase progression and delayed growth, shortening of telomeres, and accelerated senescence[95,96,97,98]. It is therefore apparent that in normal cells, the catalytic domains are involved in replicative DNA synthesis. This has been shown to be the case in human cells where Pol $\varepsilon$ can be cross-linked to nascent cellular DNA within replicating chromosomes[91] and replicative DNA synthesis is inhibited when neutralizing antibodies against Pol $\varepsilon$ are introduced into isolated nuclei or nuclei of growing cells[92]. In line with this, removal of Pol $\varepsilon$ from a Xenopus egg extract resulted in aberrant chromosomal DNA replication[99].

These results not only confirm the important role of Pol $\varepsilon$ in nuclear DNA replication, but also indicate that the enzyme actually synthesises a significant fraction of new DNA in proliferating cells. If the Pol domain is not deleted, but inactivated by mutation of the catalytic centre, yeast cells are rendered deficient in replication and therefore inviable[96]. Similarly, several yeast temperature sensitive mutants of Pol $\varepsilon$ map to the catalytic domain, and arrest replication at the restrictive temperature[93]. This raises the possibility that the $\mathrm{N}$-terminal part of Pol $\varepsilon$ blocks or disrupts the replication fork when present but inactive, but may be substituted for when it is completely absent.

\section{WHAT IS THE ROLE OF POL $\varepsilon$ IN REPLICATION?}

Several approaches have been utilised to address the division of labour between Pols $\delta$ and $\varepsilon$ in cellular DNA replication (Table 2). S. cerevisiae Pol $\varepsilon$ associates with origin DNA before the initiation of DNA replication. Upon initiation, it dissociates from the origin and associates with nonorigin DNA, with kinetics similar to those of Cdc45 and MCM proteins, probably following the replication fork[100].

A role in elongation and maturation of the lagging strand was proposed for Pol $\varepsilon$ based on biochemical properties[6]. Analysis of the phenotype of exonuclease deficient mutants of Pols $\delta$ and $\varepsilon$ showed that both Pols function consecutively with mismatch repair, i.e., in DNA replication. This finding led A. Sugino to propose that Pol $\varepsilon$ could function in leading strand synthesis, whereas Pol $\delta$ would perform the bulk of lagging strand synthesis[13,101]. This view was supported by more detailed analysis of the exo mutants placing marker genes in opposite directions in the vicinity of a replication origin in yeast[102]. In this elegant approach, mutational analysis of the marker gene in different Pol exo ${ }^{-}$backgrounds indicates that only one, but not both strands, is encountered by the defective Pol[103,104]. This again placed the two enzymes on different DNA strands. However, Datta and coworkers[105] demonstrated that the Pol $\delta$ exo ${ }^{-}$ mutator phenotype depends on the $\mathrm{S}$ phase damage checkpoint pathway, and is not a direct consequence of inaccurate DNA synthesis. There is a clear strand bias for replication errors on leading and lagging strand established by yeast origins[106]. It remains to be studied whether this bias is due to different fidelities of the two Pols at the replication fork. Burgers[49] proposed, as a modification of his earlier model, that Pol $\delta$ would elongate DNA both on the leading and lagging strands, whereas Pol $\varepsilon$ would only be required for lagging strand maturation. This model assumes that Pol $\varepsilon$ synthesises less DNA than Pol $\delta$, based predominantly on the less severe phenotype of 
TABLE 2

Proposed Functions of Pol $\varepsilon$ and Their Dependence on the Catalytic Activity of the Enzyme

\begin{tabular}{|c|c|c|c|}
\hline Function & $\begin{array}{l}\text { DNA Polymerase } \\
\text { Activity Required }\end{array}$ & Evidence & References \\
\hline \multirow[t]{5}{*}{$\begin{array}{l}\text { Nuclear DNA } \\
\text { replication }\end{array}$} & $\begin{array}{l}\text { Involved but not } \\
\quad \text { essential }\end{array}$ & Genetic analysis in S. cerevisiae and S. pombe & $\begin{array}{l}{[13,18,19} \\
35,93,94 \\
95,96]\end{array}$ \\
\hline & & Cross-linking af nascent DNA to Pols & [91] \\
\hline & & Microinjection of antibodies into human fibroblasts & [92] \\
\hline & & Replication in isolated human cell nuclei & [92] \\
\hline & & Immunodepletion of Xenopus egg extracts & [99] \\
\hline $\begin{array}{l}\text { Initiation of } \\
\text { replication }\end{array}$ & Not determined & $\begin{array}{l}\text { Biochemical analysis in S. cerevisiae and Xenopus egg } \\
\text { extracts }\end{array}$ & $\begin{array}{l}{[100,123} \\
124,130]\end{array}$ \\
\hline $\begin{array}{l}\text { Replication of } \\
\text { leading or lagging } \\
\text { strand }\end{array}$ & Yes & Analysis of exonuclease-deficient mutants in S. cerevisiae & {$[103,104]$} \\
\hline \multirow[t]{2}{*}{$\begin{array}{l}\text { Replication of } \\
\text { heterochromatin }\end{array}$} & $(\text { Yes })^{1}$ & Immunofluorescence microscopy in human fibroblasts & [122] \\
\hline & & $\begin{array}{l}\text { Histone-fold subunit shared with chromatin remodelling } \\
\text { factor }\end{array}$ & $\begin{array}{l}{[39,40,66} \\
68]\end{array}$ \\
\hline \multicolumn{4}{|l|}{ DNA repair } \\
\hline \multirow[t]{2}{*}{$\begin{array}{l}\text { Nucleotide } \\
\text { excision repair }\end{array}$} & Yes & Reconstitution of the human repair pathway & $\begin{array}{l}{[135,137} \\
139]\end{array}$ \\
\hline & & Biochemical analysis in S. cerevisiae & $\begin{array}{l}{[142,143,} \\
144]\end{array}$ \\
\hline \multirow[t]{2}{*}{$\begin{array}{l}\text { Base excision } \\
\text { repair }\end{array}$} & Yes & Reconstitution of the human repair pathway & {$[153,158]$} \\
\hline & & Biochemical analysis in S. cerevisiae & [140] \\
\hline \multirow[t]{3}{*}{ Recombination } & $(Y e s)^{1}$ & $\begin{array}{l}\text { Part of mammalian recombination complex I mediating } \\
\text { stand exchange }\end{array}$ & {$[120]$} \\
\hline & & $\begin{array}{l}\text { Purifies with a Xenopus non-homologous end joining } \\
\text { activity }\end{array}$ & [163] \\
\hline & & Genetic analysis in S. cerevisiae; & {$[110,111]$} \\
\hline $\begin{array}{l}\text { DNA damage } \\
\text { response }\end{array}$ & No & Genetic analysis in S. cerevisiae & {$[50,125,126]$} \\
\hline \multirow[t]{2}{*}{$\begin{array}{l}\text { Transcriptional } \\
\text { silencing }\end{array}$} & No & Genetic analysis in S. cerevisiae & {$[62,63]$} \\
\hline & & $\begin{array}{l}\text { Interaction of mouse B subunit with } \operatorname{Sin} 3 \text { co-repressor } \\
\text { complex }\end{array}$ & [59] \\
\hline
\end{tabular}

$1 \mathrm{~A}$ requirement for the polymerase activity of $\mathrm{Pol} \varepsilon$ for replication of heterochromatin or during recombination processes seems likely, but has not been directly proven. 
Pol $\varepsilon$ compared to Pol $\delta$ exo mutants. Since this assumption is no longer supported, and since Pol $\delta$ has been shown to be actively involved in lagging strand maturation[107,108], the Burgers model lacks conclusive evidence. An explanation of the role of Pol $\varepsilon$ should take into account differences between cellular DNA replication and the SV40 system. The larger eukaryotic genome necessitates more complex cell cycle and DNA damage checkpoint control. Pol $\delta$ appears to have an important role in replicative damage bypass by translesion synthesis[105,109].

Pol $\varepsilon$ is not only important during the initiation of DNA replication[100], but also in the recombinational processes during S-phase[110,111]. Such processes are induced by DNA breaks that may be normal and common in replicating chromosomes[110,112]. Although break-induced recombination may be explained in several ways, models that involve the formation of a replication fork are most likely[113]. These models closely resemble the mechanisms for recombination-induced late replication of the $\mathrm{T} 4$ phage and recombination-dependent replication in E. coli $[114,115,116]$. It appears that break-induced recombination is particularly important for the maintenance of telomeres in the absence of telomerase, and for the restart of DNA replication at broken replication forks[116,117,118]. Pol $\varepsilon$ seems to play a role in establishing a DNA synthesome during gene conversion[111]. Similarly it may be required for recombinationdependent DNA replication processes and it is likely that Pols $\delta$ and $\varepsilon$ cannot substitute for each other in these specific functions. Consistent with its possible role in recombination-induced replication, Pol $\varepsilon$ has been found to be a component of a human recombination complex that is able to repair deletions and double-strand breaks of DNA[119,120]. It also seems to play a specific role in completion of meiotic recombination in mouse testis[121].

The recent finding that Pol $\varepsilon$ forms nuclear foci that colocalise with sites of DNA replication in late, but not early $\mathrm{S}$ phase, provides another potential solution for the division of labour between Pols $\delta$ and $\varepsilon[122]$. These results indicate that the chromatin structure could determine which Pol replicates certain DNA; Pol $\delta$ would be responsible for the replication of more open chromatin in early S phase whereas Pol $\varepsilon$ would replicate more compact heterochromatin in late $\mathrm{S}$ phase. Support for this view seems to come from analysis of the primary structure of Pol $\varepsilon$ that provides several links to chromatin structure and remodelling. These results, however, do not explain why Pol $\varepsilon$ associates similarly with early and late firing origins in budding yeast, and is associated with the very open embryonic chromatin in Xenopus egg extracts in a replicationdependent manner[123,124]. Different models and novel approaches will be required to resolve conclusively the specific roles of Pols $\delta$ and $\varepsilon$ during cellular replication.

\section{THE ROLE OF POL $\varepsilon$ IN THE DNA DAMAGE RESPONSE}

Besides DNA replication, the putative zinc finger domain or the adjacent $\mathrm{C}$-terminus is involved in the response to DNA damage, since some of the budding yeast mutants with mutations in this region are defective in their response to DNA damaging agents during S-phase[50,125,126]. Further evidence of the checkpoint function of budding yeast Pol $\varepsilon$ comes from identification of the DPB11 gene as a multicopy suppressor of the temperature-sensitive Pol2 (encodes the catalytic subunit of Pol $\varepsilon$ ) and DPB2 (encodes the B subunit of Pol $\varepsilon$ ) mutants of Pol $\varepsilon[127]$. The gene product is homologous to the fission yeast Cut5, both having four copies of the BRCA1 Cterminal (BRCT) domain. Dpb11 and Cut5 are required for the onset of S-phase, DNA replication and cell cycle checkpoints[127,128,129]. Dpb11 also interacts physically with Pol $\varepsilon$, but this interaction appears to be transient and may be restricted to initiation of replication[130]. The topoisomerase II $\beta$ binding protein 1 (TopBP1) contains eight BRCT domains and is a structural and functional human homologue of Dpb11. It is required for DNA replication; it binds to Pol $\varepsilon$ (Fig. 1) and relocates to stalled replication forks in response to replication blocks[131,132]. It also localises to sites of DNA double strand breaks and is phosphorylated in response to the damage. This phosphorylation depends on the ataxia telangiectasia mutated protein (ATM) in 
vivo[131,132]. Recent work indicates that TopBP1 may represent an interaction platform for proteins that function in cell cycle regulation.

In contrast to the situation in budding yeast, there is no evidence for a direct involvement of Pol $\varepsilon$ in DNA checkpoint control in the fission yeast Schizosaccharomyces pombe[18]. Instead, the Pol $\sigma$ homologue Cid1 is required for S-M checkpoint control when Pol $\delta$ or $\varepsilon$ is inactivated, or DNA replication is blocked[133].

The ubiquitin ligase and oncoprotein MDM2 was found to interact with the C-terminal region of human Pol $\varepsilon[134]$ (Fig. 1). The regulatory and functional implications have not yet been studied, but one could envision that MDM2 is sequestered by Pol $\varepsilon$ in response to DNA damage, thereby stabilising $\mathrm{p} 53$. On the other hand, Pol $\varepsilon$ could be targeted by MDM2 for proteosomedependent degradation.

\section{POL $\varepsilon$ IN DNA REPAIR}

Pol $\varepsilon$ was originally isolated from HeLa cells as a factor required for the repair of UV damage in human fibroblasts[4]. Nucleotide excision repair (NER) represents the major repair pathway for this type of DNA damage. In a reconstituted system utilising UV-irradiated DNA and a mixture of purified and recombinant proteins, both calf thymus Pol $\delta$ and the $140-\mathrm{kDa}$ form of Pol $\varepsilon$ could perform the gap-filling DNA repair synthesis[135]. This is consistent with studies using model DNA substrates containing short gaps[72,136,137,138]. The Pol requirement of nucleotide excision repair was re-examined utilising highly purified recombinant incision components and highly purified human Pols[139]. DNA repair synthesis of a defined cis-platin adduct occurred also with Pol $\delta$ and Pol $\varepsilon$, and depended on PCNA and RFC for both enzymes.

The powerful genetics of budding yeast has been used extensively to analyse the Pol requirement of UV damage repair. These studies, however, suffer in part from the fact that several DNA repair pathways operate in parallel in yeast to correct this type of damage. Wang and coworkers[140] found a role for Pol $\varepsilon$ in the repair of UV damaged plasmids in S. cerevisiae nuclear extracts in an experimental set-up very similar to the one described earlier. The authors could demonstrate that their repair depended on base excision repair (BER) rather than NER[141]. Analysis of changes in the molecular weight of cellular DNA after UV irradiation in various mutant backgrounds was used to determine the Pol requirement of the repair[142,143,144]. In all studies, Pol $\delta$ and Pol $\varepsilon$ were implicated in the filling of repair gaps that were formed in a Rad1 (NER)-dependent manner, but whereas the former study indicated redundancy of the two Pols, the latter two suggested that the presence of both enzymes is required for repair of the UV lesions.

In mammalian BER, either a short-patch or a long-patch repair pathway may be utilised[145,146,147,148]. In short patch BER, which appears to be the major BER pathway, a gap of usually only one nucleotide is created during repair and filled by Pol $\beta[145,149]$. The repair is then completed by sealing the remaining nick utilising the complex of DNA ligase III and XRCC1[149,150]. DNA ligase I may possibly substitute for the XRCC1/ligase III in some instances[147,151]. According to recent reports, Pol $\beta$ also initiates regular long-patch BER, which involves synthesis of 2-8 nucleotides beginning at the damage site[146,152,153,154,155,156,157]. Poly(ADP-ribose) polymerase-1 (PARP-1) is required for a switch to initiate long-patch BER when the repair product cannot be ligated after incorporation of the first nucleotide by Pol $\beta[155,156,157]$. In this case, Pol $\beta$ is replaced by Pols $\delta$ or $\varepsilon$, which then conducts strand displacement synthesis[153,158]. DNA synthesis is directed by the DNA sliding clamp PCNA and the clamp loader RFC, and the displaced DNA is removed as an oligonucleotide by the flap endonuclease Fen-1[159,160]. Repair is completed by DNA ligase I or alternatively by XRCC1/ligase III. PCNA probably has an important role in coordination of this pathway since it interacts with Pol $\delta / \varepsilon$, Fen-1, and DNA ligase I[152,160,161,162]. 
Besides the role in homologous recombination processes that have already been discussed, Pol $\varepsilon$ has also been identified in a partially purified nonhomologous end-joining (NHEJ) activity[163]. This activity probably represents a minor NHEJ pathway not dependent on DNAdependent protein kinase that joins noncomplementary DNA ends without a requirement for homology, but with the generation of deletions. In addition to Pol $\varepsilon$, the 5 '-specific FEN-1, DNA ligase III, and possibly PCNA are involved in this pathway[163,164].

While Pols $\delta$ and $\varepsilon$ appear to be largely redundant during NER and long patch BER, these two Pols also have nonredundant functions in DNA repair. As described, Pol $\varepsilon$ has been repeatedly implicated in recombinational processes, whereas Pol $\delta$ apparently fulfils specific functions during mismatch repair as well as postreplicational repair by DNA translesion synthesis[109,165,166].

\section{CONCLUSIONS}

Pol $\varepsilon$ is an enzyme of both complex structure and function. As presented in this review, Pol $\varepsilon$ shares several structural and functional features with archaeal Pols of family B on the one hand, and with the related eukaryotic replicative Pol $\delta$ on the other. However, Pol $\varepsilon$ differs from these Pols in that it possesses a large C-terminal domain that is not required for its enzymatic function. It appears that this domain mediates many of the functions of Pol $\varepsilon$, and it is this region, but not the Pol domain, that renders Pol $\varepsilon$ indispensable for cell viability. Even 30 years after its first isolation, Pol $\varepsilon$ still offers surprises. Understanding the function of Pol $\varepsilon$ is a prerequisite for understanding the mechanisms of eukaryotic DNA replication and the maintenance of genome integrity in general.

\section{ACKNOWLEDGEMENTS}

J.E.S. is supported by the Academy of Finland and the Cancer Society of Finland.

\section{REFERENCES}

1. Wintersberger, U. and Wintersberger, E. (1970) Studies on deoxyribonucleic acid polymerases from yeast. 1. Parial purification and properties of two DNA polymerases from mitochondria-free cell extracts. Eur. J. Biochem. 13, 11-19.

2. Byrnes, J.J., Downey, K.M., Black, V.L., and So, A.G. (1976) A new mammalian DNA polymerase with 3' to 5' exonuclease activity: DNA polymerase $\delta$. Biochemistry 15, 2817-2823.

3. Lee, M.Y.W.T. and Toomey, N.L. (1987) Human placental DNA polymerase $\delta$ : identification of a 170kilodalton polypeptide by activity staining and immunoblotting. Biochemistry 26, 1076-1085.

4. Nishida, C., Reinhard, P., and Linn, S. (1988) DNA repair synthesis in human fibroblasts requires DNA polymerase $\delta$. J. Biol. Chem. 263, 501-510.

5. Syväoja, J. and Linn, S. (1989) Characterization of a large form of DNA polymerase $\delta$ from HeLa cells that is insensitive to proliferating cell nuclear antigen. J. Biol. Chem. 264, 2489-2497.

6. Lee, S.-H., Pan, Z.-Q., Kwong, A.D., Burgers, P.M.J., and Hurwitz, J. (1991) Synthesis of DNA by DNA polymerase $\varepsilon$ in vitro. J. Biol. Chem. 266, 22707-22717.

7. Crute, J.J., Wahl, A.F., and Bambara, R.A. (1986) Purification and characterization of two new high molecular weight forms of DNA polymerase $\delta$. Biochemistry 25, 26-36.

8. Focher, F., Spadari, S., Ginelli, B., Hottiger, M., Gassmann, M., and Hübscher, U. (1988) Calf thymus DNA polymerase $\delta$ : purification, biochemical and functional properties of the enzyme after its separation from DNA polymerase $\alpha$, a DNA dependent ATPase and proliferating cell nuclear antigen. Nucleic Acids Res. 16, 62796295 .

9. Uitto, L., Halleen, J., Hentunen, T., Höyhtyä, M., and Syväoja, J.E. (1995) Structural relationship between DNA polymerases $\varepsilon$ and $\varepsilon^{*}$ and their occurrence in eukaryotic cells. Nucleic Acids Res. 23, 244-247. 
10. Liu, W. and Linn, S. (2000) Proteolysis of the human DNA polymerase $\varepsilon$ catalytic subunit by caspase-3 and calpain specifically during apoptosis. Nucleic Acids Res. 28, 4180-4188.

11. Syväoja, J.E. (1990) DNA polymerase epsilon: the latest member in the family of mammalian DNA polymerases. Bioessays 12, 533-536.

12. Wong, S.W., Syväoja, J., Tan, C.K., Downey, K.M., So, A.G., Linn, S., and Wang, T.S.-F. (1989) DNA polymerases $\alpha$ and $\delta$ are immunologically and structurally distinct. J. Biol. Chem. 264, 5924-5928.

13. Morrison, A., Araki, H., Clark, A.B., Hamatake, R.K., and Sugino, A. (1990) A third essential DNA polymerase in S. cerevisiae. Cell 62, 1143-1151.

14. Syväoja, J., Suomensaari, S., Nishida, C., Goldsmith, J.S., Chui, G.S., Jain, S., and Linn, S. (1990) DNA polymerases $\alpha, \delta$, and $\varepsilon$ : three distinct enzymes from HeLa cells. Proc. Natl. Acad. Sci. U. S. A. 87, 6664-6668.

15. Lee, M.Y.W.T., Jiang, Y.Q., Zhang, S.J., and Toomey, N.L. (1991) Characterization of human DNA polymerase $\delta$ and its immunochemical relationships with DNA polymerase $\alpha$ and $\varepsilon$. J. Biol. Chem. 266, 24232429.

16. Kesti, T., Frantti, H., and Syväoja, J.E. (1993) Molecular cloning of the cDNA for the catalytic subunit of human DNA polymerase $\varepsilon$. J. Biol. Chem. 268, 10238-10245.

17. Aoyagi, N., Oshige, M., Hirose, F., Kuroda, K., Matsukage, A., and Sakaguchi, K. (1997) DNA polymerase $\varepsilon$ from Drosophila melanogaster. Biochem. Biophys. Res. Commun. 230, 297-301.

18. D'Urso, G. and Nurse, P. (1997) Schizosaccharomyces pombe cdc20+ encodes DNA polymerase $\varepsilon$ and is required for chromosomal replication but not for the $\mathrm{S}$ phase checkpoint. Proc. Natl. Acad. Sci. U. S. A. 94, 12491-12496.

19. Sugino, A., Ohara, T., Sebastian, J., Nakashima, N., and Araki, H. (1998) DNA polymerase $\varepsilon$ encoded by $c d c 20+$ is required for chromosomal DNA replication in the fission yeast Schizosaccharomyces pombe. Genes Cells 3, 99-110.

20. Oshige, M., Yoshida, H., Hirose, F., Takata, K.-I., Inoue, Y., Aoyagi, N., Yamaguchi, M., Koiwai, O., Matsukage, A., and Sakaguchi, K. (2000) Molecular cloning and expression during development of the Drosophila gene for the catalytic subunit of DNA polymerase $\varepsilon$. Gene 256, 93-100.

21. Ito, J. and Braithwaite, D.K. (1991) Compilation and alignment of DNA polymerase sequences. Nucleic Acids Res. 19, 4045-4057.

22. Braithwaite, D.K. and Ito, J. (1993) Compilation, alignment, and phylogenetic relationships of DNA polymerases. Nucleic Acids Res. 21, 787-802.

23. Huang, D., Knuuti, R., Palosaari, H., Pospiech, H., and Syväoja, J.E. (1999) cDNA and structural organization of the gene Pole1 for the mouse DNA polymerase $\varepsilon$ catalytic subunit. Biochim. Biophys. Acta 1445, 363-371.

24. Edgell, D.R., Malik, S.-B., and Doolittle, W.F. (1998) Evidence of independent gene duplications during the evolution of archaeal and eukaryotic family B DNA polymerases. Mol. Biol. Evol. 15, 1207-1217.

25. Iwai, T., Kurosawa, N., Itoh, Y.H., Kimura, N., and Horiuchi, T. (2000) Sequence analysis of three family B DNA polymerases from the thermoacidophilic crenarchaeon Sulfurisphaera ohwakuensis. DNA Res. 7, 243251.

26. Edgell, D.R., Klenk, H.-P., and Doolittle, W.F. (1997) Gene duplications in evolution of archaeal family B DNA polymerases. J. Bacteriol. 179, 2632-2640.

27. Cann, I.K.O. and Ishino, Y. (1999) Archaeal DNA replication: identifying the pieces to solve a puzzle. Genetics 152, 1249-1267.

28. Bernad, A., Blanco, L., Lázaro, J.M., Martín, G., and Salas, M. (1989) A conserved 3' $\rightarrow 5^{\prime}$ exonuclease active site in prokaryotic and eukaryotic DNA polymerases. Cell 59, 219-228.

29. de Vega, M., Ilyina, T., Lázaro, J.M., Salas, M., and Blanco, L. (1997) An invariant lysine residue is involved in catalysis at the $3^{\prime}-5^{\prime}$ exonuclease active site of eukaryotic-type DNA polymerases. J. Mol. Biol. 270, 65-78.

30. de Vega, M., Lázaro, J.M., Salas, M., and Blanco, L. (1998) Mutational analysis of Ф29 DNA polymerase residues acting as ssDNA ligands for 3' -5 ' exonucleolysis. J. Mol. Biol. 279, 807-822.

31. Wang, T.S.-F., Wong, S.W., and Korn, D. (1989) Human DNA polymerase $\alpha$ : predicted functional domains and relationships with viral DNA polymerases. FASEB J. 3, 14-21.

32. Damagnez, V., Tillit, J., de Recondo, A.M., and Baldacci, G. (1991) The POL1 gene from the fission yeast, Schizosaccharomyces pombe, shows conserved amino acid blocks specific for eukaryotic DNA polymerases $\alpha$. Mol. Gen. Genet. 226, 182-189.

33. Yang, C.L., Chang, L.S., Zhang, P., Hao, H., Zhu, L., Toomey, N.L., and Lee, M.Y.W.T. (1992) Molecular cloning of the cDNA for the catalytic subunit of human DNA polymerase $\delta$. Nucleic Acids Res. 20, 735-745.

34. Hübscher, U., Nasheuer, H.-P., and Syväoja, J.E. (2000) Eukaryotic DNA polymerases, a growing family. Trends Biochem. Sci. 25, 143-147.

35. Araki, H., Hamatake, R.K., Johnston, L.H., and Sugino, A. (1991) DPB2, the gene encoding DNA polymerase II subunit B, is required for chromosome replication in Saccharomyces cerevisiae. Proc. Natl. Acad. Sci. U. S. A. 88, 4601-4605.

36. Li, Y., Asahara, H., Patel, V.S., Zhou, S., and Linn, S. (1997) Purification, cDNA cloning, and gene mapping of the small subunit of human DNA polymerase $\varepsilon$. J. Biol. Chem. 272, 32337-32344.

37. Jokela, M., Mäkiniemi, M., Lehtonen, S., Szpirer, C., Hellman, U., and Syväoja, J.E. (1998) The small subunits of human and mouse DNA polymerase $\varepsilon$ are homologous to the second largest subunit of the yeast 
Saccharomyces cerevisiae DNA polymerase $\varepsilon$. Nucleic Acids Res. 26, 730-734.

38. Araki, H., Hamatake, R.K., Morrison, A., Johnson, A.L., Johnston, L.H., and Sugino, A. (1991) Cloning DPB3, the gene encoding the third subunit of DNA polymerase II of Saccharomyces cerevisiae. Nucleic Acids Res. 19, 4867-4872.

39. Ohya, T., Maki, S., Kawasaki, Y., and Sugino, A. (2000) Structure and function of the fourth subunit (Dpb4p) of DNA polymerase $\varepsilon$ in Saccharomyces cerevisiae. Nucleic Acids Res. 28, 3846-3852.

40. Li, Y., Pursell, Z.F., and Linn, S. (2000) Identification and cloning of two histone fold motif-containing subunits of HeLa DNA polymerase $\varepsilon$. J. Biol. Chem. 275, 23247-23252.

41. Hamatake, R.K., Hasegawa, H., Clark, A.B., Bebenek, K., Kunkel, T.A., and Sugino, A. (1990) Purification and characterization of DNA polymerase II from the yeast Saccharomyces cerevisiae. Identification of the catalytic core and a possible holoenzyme form of the enzyme. J. Biol. Chem. 265, 4072-4083. cerevisiae DNA polymerase $\varepsilon$ in insect cells. Purification and characterization. J. Biol. Chem. 277, 7889-7896.

43. Chilkova, O., Jonsson, B.H., and Johansson, E. (2003) The quarternary structure of DNA polymerase epsilon from S. cerevisiae. J. Biol. Chem., epub ahead of print on February 5.

44. Mäkiniemi, M., Pospiech, H., Kilpeläinen, S., Jokela, M., Vihinen, M., and Syväoja, J.E. (1999) A novel family of DNA-polymerase-associated B subunits. Trends Biochem. Sci. 24, 14-16.

45. Uemori, T., Sato, Y., Kato, I., Doi, H., and Ishino, Y. (1997) A novel DNA polymerase in the hyperthermophilic archaeon, Pyrococcus furiosus: gene cloning, expression and characterization. Genes Cells 2, 499-512.

46. Ishino, Y., Komori, K., Cann, I.K.O., and Koga, Y. (1998) A novel DNA polymerase family found in archaea. J. Bacteriol. 180, 2232-2236.

47. Giot, L., Chanet, R., Simon, M., Facca, C., and Faye, G. (1997) Involvement of the yeast DNA polymerase $\delta$ in DNA repair in vivo. Genetics 146, 1239-1251.

48. Ishino, Y. and Cann, I.K.O. (1998) The euryarchaeotes, a subdomain of Archaea, survive on a single DNA polymerase: fact or farce? Genes Genet. Syst. 73, 323-336.

49. Burgers, P.M.J. (1998) Eukaryotic DNA polymerases in DNA replication and DNA repair. Chromosoma 107, $218-227$.

50. Dua, R., Levy, D.L., and Campbell, J.L. (1998) Role of the putative zinc finger domain of Saccharomyces cerevisiae DNA polymerase $\varepsilon$ in DNA replication and the S/M checkpoint pathway. J. Biol. Chem. 273, 30046-30055.

51. Dua, R., Edwards, S., Levy, D.L., and Campbell, J.L. (2000) Subunit interactions within the Saccharomyces cerevisiae DNA polymerase $\varepsilon$ (pol $\varepsilon$ ) complex. Demonstration of a dimeric pol $\varepsilon$. J. Biol. Chem. 275, 2881628825.

52. Aravind, L. and Koonin, E.V. (1998) Phosphoesterase domains associated with DNA polymerases of diverse origins. Nucleic Acids Res. 26, 3746-3752.

53. Koonin, E.V. (1994) Conserved sequence pattern in a wide variety of phosphoesterases. Protein Sci. 3, 356358.

54. Goldberg, J., Huang, H.B., Kwon, Y.G., Greengard, P., Nairn, A.C., and Kuriyan, J. (1995) Three-dimensional structure of the catalytic subunit of protein serine/threonine phosphatase-1. Nature 376, 745-753.

55. Lohse, D.L., Denu, J.M., and Dixon, J.E. (1995) Insights derived from the structures of the Ser/Thr phosphatases calcineurin and protein phosphatase 1. Structure 3, 987-990.

56. Murzin, A.G. (1993) OB(oligonucleotide/oligosaccharide binding)-fold: common structural and functional solution for non-homologous sequences). EMBO J. 12, 861-867.

57. Koonin, E.V., Wolf, Y.I., and Aravind, L. (2000) Protein fold recognition using sequence profiles and its application in structural genomics. Adv. Protein Chem. 54, 245-275.

58. Gueguen, Y., Rolland, J.L., Lecompte, O., Azam, P., Le Romancer, G., Flament, D., Raffin, J.-P., and Dietrich, J. (2001) Characterization of two DNA polymerases from the hyperthermophilic euryarchaeon Pyrococcus abyssi. Eur. J. Biochem. 268, 5961-5969.

59. Wada, M., Miyazawa, H., Wang, R.-S., Mizuno, T., Sato, A., Asashima, M., and Hanaoka, F. (2002) The second largest subunit of mouse DNA polymerase $\varepsilon$, DPE2, interacts with SAP18 and recruits the Sin3 Corepressor protein to DNA. J. Biochem. (Tokyo) 131, 307-311.

60. Ng, H.H. and Bird, A. (2000) Histone deacetylases: silencers for hire. Trends Biochem. Sci. 25, 121-126.

61. Lai, A., Kennedy, B.K., Barbie, D.A., Bertos, N.R., Yang, X.J., Theberge, M.-C., Tsai, S.-C., Seto, E., Zhang, Y., Kuzmichev, A., Lane, W.S., Reinberg, D., Harlow, E., and Branton, P.E. (2001) RBP1 recruits the mSIN3histone deacetylase complex to the pocket of retinoblastoma tumor suppressor family proteins found in limited discrete regions of the nucleus at growth arrest. Mol. Cell. Biol. 21, 2918-2932.

62. Ehrenhofer-Murray, A.E., Kamakaka, R.T., and Rine, J. (1999) A role for the replication proteins PCNA, RF$\mathrm{C}$, polymerase $\varepsilon$ and Cdc45 in transcriptional silencing in Saccharomyces cerevisiae. Genetics 153, 1171-1182.

63. Smith, J.S., Caputo, E., and Boeke, J.D. (1999) A genetic screen for ribosomal DNA silencing defects identifies multiple DNA replication and chromatin-modulating factors. Mol. Cell. Biol. 19, 3184-3197.

64. Kirchmaier, A.L. and Rine, J. (2001) DNA Replication-independent silencing in S. cerevisiae. Science 291, 646-650

65. Li, Y.-C., Cheng, T.-H., and Gartenberg, M.R. (2001) Establishment of transcriptional silencing in the absence 
of DNA replication. Science 291, 650-653.

66. Poot, R.A., Dellaire, G., Hulsmann, B.B., Grimaldi, M.A., Corona, D.F.V., Becker, P.B., Bickmore, W.A., and Varga-Weisz, P.D. (2000) HuCHRAC, a human ISWI chromatin remodelling complex contains hACF1 and two novel histone-fold proteins. EMBO J. 19, 3377-3387.

67. Corona, D.F.V., Eberharter, A., Budde, A., Deuring, R., Ferrari, S., Varga-Weisz, P., Wilm, M., Tamkun, J., and Becker, P.B. (2000) Two histone fold proteins, CHRAC-14 and CHRAC-16, are developmentally regulated subunits of chromatin accessibility complex (CHRAC). EMBO J. 19, 3049-3059.

68. Bolognese, F., Imbriano, C., Caretti, G., and Mantovani, R. (2000) Cloning and characterization of the histonefold proteins YBL1 and YCL1. Nucleic Acids Res. 28, 3830-3838.

69. Vandenbol, M. and Portetelle, D. (1999) Disruption of six ORFs on Saccharomyces cerevisiae chromosome X: the YJL069c gene of unkown function is essential to cell viability. Yeast 15, 1411-1417.

70. Podust, V.N., Georgaki, A., Strack, B., and Hübscher, U. (1992) Calf thymus RF-C as an essential component for DNA polymerase $\delta$ and $\varepsilon$ holoenzymes function. Nucleic Acids Res. 20, 4159-4165.

71. Maga, G. and Hübscher, U. (1995) DNA polymerase $\varepsilon$ interacts with proliferating cell nuclear antigen in primer recognition and elongation. Biochemistry 34, 891-901.

72. Mozzherin, D.J. and Fisher, P.A. (1996) Human DNA polymerase $\varepsilon$ : enzymologic mechanism and gap-filling synthesis. Biochemistry 35, 3572-3577.

73. Maki, S., Hashimoto, K., Ohara, T., and Sugino, A. (1998) DNA polymerase II ( $\varepsilon$ ) of Saccharomyces cerevisiae dissociates from the DNA template by sensing single-stranded DNA. J. Biol. Chem. 273, 2133221341.

74. Eissenberg, J.C., Ayyagari, R., Gomes, X.V., and Burgers, P.M.J. (1997) Mutations in yeast proliferating cell nuclear antigen define distinct sites for interaction with DNA polymerase $\delta$ and DNA polymerase $\varepsilon$. Mol. Cell. Biol. 17, 6367-6378.

75. Kelman, Z., Zuo, S., Arroyo, M.P., Wang, T.S.-F., and Hurwitz, J. (1999) The C-terminal region of Schizosaccharomyces pombe proliferating cell nuclear antigen is essential for DNA polymerase activity. Proc. Natl. Acad. Sci. U. S. A. 96, 9515-9520.

76. Maga, G., Jónsson, Z.O., Stucki, M., Spadari, S., and Hübscher, U. (1999) Dual mode of interaction of DNA polymerase $\varepsilon$ with proliferating cell nuclear antigen in primer binding and DNA synthesis. J. Mol. Biol. 285, $259-267$.

77. Warbrick, E., Lane, D.P., Glover, D.M., and Cox, L.S. (1995) A small peptide inhibitor of DNA replication defines the site of interaction between the cyclin-dependent kinase inhibitor $\mathrm{p} 21^{\mathrm{WAF} 1}$ and proliferating cell nuclear antigen. Curr. Biol. 5, 275-282.

78. Gomes X.V. and Burgers, P.M.J. (2000) Two modes of FEN1 binding to PCNA regulated by DNA. EMBO J. 19, 3811-3821.

79. Cann, I.K., Ishino, S., Hayashi, I., Komori, K., Toh, H., Morikawa, K., and Ishino, Y. (1999) Functional interactions of a homolog of proliferating cell nuclear antigen with DNA polymerases in Archaea. J. Bacteriol. 181, 6591-6599.

80. De Felice, M., Sensen, C.W., Charlebois, R.L., Rossi, M., and Pisani, F.M. (1999) Two DNA polymerase sliding clamps from the thermophilic archaeon Sulfolobus solfatoricus. J. Mol. Biol. 291, 47-57.

81. Daimon, K., Kawarabayasi, Y., Kikuchi, H., Sako, Y., and Ishino, Y. (2002) Three proliferating cell nuclear antigen-like proteins found in the hyperthermophilic archaeon Aeropyrum pernix: interactions with the two DNA polymerases. J. Bacteriol. 184, 687-694.

82. Chui, G. and Linn, S. (1995) Further characterization of HeLa DNA polymerase E. J. Biol. Chem. 270, 77997808.

83. Li, J.J. and Kelly, T.J. (1984) Simian virus 40 DNA replication in vitro. Proc. Natl. Acad. Sci. U. S. A. 81, 6973-6977.

84. Kelly, T.J. (1988) SV40 DNA replication. J. Biol. Chem. 263, 17889-17892.

85. Weinberg, D.H. and Kelly, T.J. (1989) Requirement for two DNA polymerases in the replication of simian virus 40 DNA in vitro. Proc. Natl. Acad. Sci. U. S. A. 86, 9742-9746.

86. Nethanel, T. and Kaufmann, G. (1990) Two DNA polymerases may be required for synthesis of the lagging strand DNA of simian virus 40. J. Virol. 64, 5912-5918.

87. Weinberg, D.H., Collins, K.L., Simancek, P., Russo, A., Wold, M.S., Virshup, D.M., and Kelly, T.J. (1990) Reconstitution of simian virus 40 DNA replication with purified proteins. Proc. Natl. Acad. Sci. U. S. A. 87, 8692-8696.

88. Tsurimoto, T., Melendy, T., and Stillman, B. (1990) Sequencial initiation of lagging and leading strand synthesis by two different polymerase complexes at the SV40 DNA replication origin. Nature 346, 534-539.

89. Waga, S. and Stillman, B. (1994) Anatomy of a DNA replication fork revealed by reconstitution of SV40 DNA replication in vitro. Nature 369, 207-212.

90. Waga, S., Bauer, G., and Stillman, B. (1994) Reconstitution of complete SV40 DNA replication with purified replication factors. J. Biol. Chem. 269, 10923-10934.

91. Zlotkin, T., Kaufmann, G., Jiang, Y., Lee, M.Y.W.T., Uitto, L., Syväoja, J., Dornreiter, I., Fanning, E., and Nethanel, T. (1996) DNA polymerase $\varepsilon$ may be dispensable for SV40- but not cellular-DNA replication. EMBO J. 15, 2298-2305.

92. Pospiech, H., Kursula, I., Abdel-Aziz, W., Malkas, L., Uitto, L., Kastelli, M., Vihinen-Ranta, M., Eskelinen, S., 
and Syväoja, J.E. (1999) A neutralizing antibody against human DNA polymerase $\varepsilon$ inhibits cellular but not SV40 DNA replication. Nucleic Acids Res. 27, 3799-3804.

93. Araki, H., Ropp, P.A., Johnson, A.L., Johnston, L.H., Morrison, A., and Sugino, A. (1992) DNA polymerase II, the probable homolog of mammalian DNA polymerase $\varepsilon$, replicates chromosomal DNA in the yeast Saccharomyces cerevisiae. EMBO J. 11, 733-740.

94. Budd, M.E. and Campbell, J.L. (1993) DNA polymerases $\delta$ and $\varepsilon$ are required for chromosomal replication in Saccharomyces cerevisiae. Mol. Cell. Biol. 13, 496-505.

95. Kesti, T., Flick, K., Keranen, S., Syväoja, J.E., and Wittenberg, C. (1999) DNA polymerase $\varepsilon$ catalytic domains are dispensable for DNA replication, DNA repair, and cell viability. Mol. Cell 3, 679-685.

96. Dua, R., Levy, D.L., and Campbell, J.L. (1999) Analysis of the essential functions of the C-terminal protein/protein interaction domain of Saccharomyces cerevisiae pol $\varepsilon$ and its unexpected ability to support growth in the absence of the DNA polymerase domain. J. Biol. Chem. 274, 22283-22288.

97. Feng, W. and D'Urso, G. (2001) Schizosaccharomyces pombe cells lacking the amino-terminal catalytic domains of DNA polymerase $\varepsilon$ are viable but require the DNA damage checkpoint control. Mol. Cell. Biol. 21, 4495-4504.

98. Ohya, T., Kawasaki, Y., Hiraga, S., Kanbara, S., Nakajo, K., Nakashima, N., Suzuki, A., and Sugino, A. (2002) The DNA polymerase domain of pol $\varepsilon$ is required for rapid, efficient, and highly accurate chromosomal DNA replication, telomere length maintenance, and normal cell senescence in Saccharomyces cerevisiae. J. Biol. Chem. 277, 28099-28108.

99. Waga, S., Masuda, T., Takisawa, H., and Sugino, A. (2001) DNA polymerase $\varepsilon$ is required for coordinated and efficient chromosomal DNA replication in Xenopus egg extracts. Proc. Natl. Acad. Sci. U. S. A. 98, 4978-4983.

100. Aparacio, O.M., Weinstein, D.M., and Bell, S.P. (1997) Components and dynamics of DNA replication complexes in S. cerevisiae: redistribution of MCM proteins and Cdc45p during S phase. Cell 91, 59-69.

101. Sugino, A. (1995) Yeast DNA polymerases and their role at the replication fork. Trends Biochem. Sci. 20, 319323.

102. Shcherbakova, P.V., Noskov, V.N., Pshenichnov, M.R., and Pavlov, Y.I. (1996) Base analog 6-Nhydroxylaminopurine mutagenesis in the yeast Saccharomyces cerevisiae is controlled by replicative DNA polymerases. Mutat. Res. 369, 33-44.

103. Shcherbakova, P.V. and Pavlov, Y.I. (1996) $3^{\prime} \rightarrow 5^{\prime}$ exonucleases of DNA polymerases $\varepsilon$ and $\delta$ correct base analog induced DNA replication errors on opposite DNA strands in Saccharomyces cerevisiae. Genetics 142 , 717-726.

104. Karthikeyan, R., Vonarx, E.J., Straffon, A.F.L., Simon, M., Faye, G., and Kunz, B.A. (2000) Evidence from mutational specificity studies that yeast DNA polymerases $\delta$ and $\varepsilon$ replicate different DNA strands at an intracellular replication fork. J. Mol. Biol. 299, 405-419.

105. Datta, A., Schmeits, J.L., Amin, N.S., Lau, P.J., Myung, K., and Kolodner, R.D. (2000) Checkpoint-dependent activation of mutagenic repair in Saccharomyces cerevisiae pol3-01 mutants. Mol. Cell 6, 593-603.

106. Pavlov, Y.I., Newlon, C.S., and Kunkel, T.A. (2002) Yeast origins establish a strand bias for replicational mutagenesis. Mol. Cell 10, 207-213.

107. Jin, Y.H., Obert, R., Burgers, P.M.J., Kunkel, T.A., Resnick, M.A., and Gordenin, D.A. (2001) The 3' $\rightarrow 5^{\prime}$ exonuclease of DNA polymerase $\delta$ can substitute for the $5^{\prime}$ flap endonuclease Rad27/Fen1 in processing Okazaki fragments and preventing genome instability. Proc. Natl. Acad. Sci. U. S. A. 98, 5122-5127.

108. Maga, G., Villani, G., Tillement, V., Stucki, M., Locatelli, G.A., Frouin, I., Spadari, S., and Hübscher, U. (2001) Okazaki fragment processing: modulation of the strand displacement activity of DNA polymerase $\delta$ by the concerted action of replication protein A, proliferating cell nuclear antigen, and flap endonuclease-1. Proc. Natl. Acad. Sci. U. S. A. 98, 14298-14303.

109. Haracska, L., Unk, I., Johnson, R.E., Burgers, P.M.J., Prakash, S., and Prakash, L. (2001) Role of DNA polymerases $\delta$ and $\zeta$ and of Rev1 in the bypass of abasic sites. Genes Dev. 15, 945-954.

110. Zou, H. and Rothstein, R. (1997) Holliday junctions accumulate in replication mutants via a RecA homologindependent mechanism. Cell 90, 87-96.

111. Holmes, A.M. and Haber, J.E. (1999) Double-strand break repair in yeast requires both leading and lagging strand DNA polymerases. Cell 96, 415-424.

112. Bénard, M., Maric, C., and Pierron, G. (2001) DNA replication-dependent formation of joint molecules in Physarum polycephalum. Mol. Cell 7, 971-980.

113. Haber, J.E. (1999) DNA recombination: the replication connection. Trends Biochem. Sci. 24, $271-275$.

114. Mosig, G. (1987) The essential role of recombination in phage T4 growth. Annu. Rev. Genet. 21, 347-371.

115. Kogoma, T. (1997) Stable DNA replication: interplay between DNA replication, homologous recombination, and transcription. Microbiol. Mol. Biol. Rev. 61, 212-238.

116. Kraus, E., Leung, W.-Y., and Haber, J.E. (2001) Break-induced replication: a review and an example in budding yeast. Proc. Natl. Acad. Sci. U. S. A. 98, 8255-8262.

117. Arnaudeau, C., Lundin, C., and Helleday, T. (2001) DNA double strand breaks associated with replication forks are predominantly repaired by homologous recombination involving an exchange mechanism in mammalian cells. J. Mol. Biol. 307, 1235-1245.

118. Michel, B., Flores, M.-J., Viguera, E., Grompone, G., Seigneur, M., and Bidnenko, V. (2001) Rescue of 
arrested replication forks by homologous recombination. Proc. Natl. Acad. Sci. U. S. A. 98, 8181-8188.

119. Jessberger, R., Podust, V., Hübscher, U., and Berg, P. (1993) A mammalian protein complex that repairs double-strand breaks and deletions by recombination. J. Biol. Chem. 268, 15070-15079.

120. Jessberger, R., Chui, G., Linn, S., and Kemper, B. (1996) Analysis of the mammalian recombination protein complex RC-1. Mutat. Res. 350, 217-227.

121. Kamel, D., Mackey, Z.B., Sjoblom, T., Walter, C.A., McCarrey, J.R., Uitto, L., Palosaari, H., Lähdetie, J., Tomkinson, A.E., and Syväoja, J.E. (1997 Role of deoxyribonucleic acid polymerase $\varepsilon$ in spermatogenesis in mice. Biol. Reprod. 57, 1367-1374.

122. Fuss, G. and Linn, S. (2002) Human DNA polymerase $\varepsilon$ colocalizes with PCNA and DNA replication late, but not early in S phase. J. Biol. Chem. 277, 8658-8666.

123. Aparacio, O.M., Stout, A.M., and Bell, S.P. (1999) Differential assembly of Cdc45p and DNA polymerases at early and late origins of DNA replication. Proc. Natl. Acad. Sci. U. S. A. 96, 9130-9135.

124. Mimura, S., Masuda, T., Matsui, T., and Takisawa, H. (2000) Central role for Cdc45 in establishing an initiation complex of DNA replication in Xenopus egg extract. Genes Cells 5, 439-452.

125. Navas, T.A., Zhou, Z., and Elledge, S.J. (1995) DNA polymerase $\varepsilon$ links the DNA replication machinery to the S phase checkpoint. Cell 80, 29-39.

126. Navas, T.A., Sanchez, Y., and Elledge, S.J. (1996) RAD9 and DNA polymerase $\varepsilon$ form parallel sensory branches for transducing the DNA damage checkpoint signal in Saccharomyces cerevisiae. Genes Dev. 10, 2632-2643.

127. Araki, H., Leem, S.-H., Phongdara, A., and Sugino, A. (1995). Dpb11, which interacts with DNA polymerase II(E) in Saccharomyces cerevisiae, has a dual role in S-phase progression and at a cell cycle checkpoint. Proc. Natl. Acad. Sci. U. S. A. 92, 11791-11795.

128. Reid, R.J.D., Fiorani, P., Sugawara, M., and Bjornsti, M.A. (1999) CDC45 and DPB11 are required for processive DNA replication and resistance to DNA topoisomerase I-mediated DNA damage. Proc. Natl. Acad. Sci. U. S. A. 96, 11440-11445.

129. Saka, Y. and Yanagida, M. (1993) Fission yeast $c u t 5^{+}$, required for S phase onset and M phase restraint, is identical to the radiation-damage repair gene $\mathrm{rad4}^{+}$. Cell 74, 383-393.

130. Masumoto, H., Sugino, A., and Araki, H. (2000) Dpb11 controls the association between DNA polymerases $\alpha$ and $\varepsilon$ and the autonomously replicating sequence region of budding yeast. Mol. Cell. Biol. 20, 2809-2817.

131. Mäkiniemi, M., Hillukkala, T., Tuusa, J., Reini, K., Vaara, M., Huang, D., Pospiech, H., Majuri, I., Westerling, T., Mäkelä, T.P., and Syväoja. J.E. (2001) BRCT domain-containing protein TopBP1 functions in DNA replication and damage response. J. Biol. Chem. 276, 30399-30406.

132. Yamane, K., Wu, X., and Chen, J. (2002) A DNA damage-regulated BRCT-containing protein, TopBP1, is required for cell survival. Mol. Cell. Biol. 22, 555-566.

133. Wang, S.-W., Toda, T., MacCallum, R., Harris, A.L., and Norbury, C. (2000) Cid1, a fission yeast protein required for S-M checkpoint control when DNA polymerase $\delta$ or $\varepsilon$ is inactivated. Mol. Cell. Biol. 20, 3234 3244.

134. Vlatkovic, N., Guerrera, S., Li, Y., Linn, S., Haines, D.S., and Boyd, M.T. (2000) MDM2 interacts with the Cterminus of the catalytic subunit of DNA polymerase $\varepsilon$. Nucleic Acids Res. 28, 3581-3586.

135. Aboussekhra, A., Biggerstaff, M., Shivji, M.K.K., Vilpo, J.A., Moncollin, V., Podust, V.N., Protić, M., Hübscher, U., Egly, J.-M., and Wood, R.D. (1995) Mammalian DNA nucleotide excision repair reconstituted with purified protein components. Cell 80, 859-868.

136. Podust, V.N. and Hübscher, U. (1993) Lagging strand DNA synthesis by calf thymus DNA polymerases $\alpha, \beta, \delta$ and $\varepsilon$ in the presence of auxiliary proteins. Nucleic Acids Res. 21, 841-846.

137. Shivji, M.K.K., Podust, V.N., Hübscher, U., and Wood, R.D. (1995) Nucleotide excision repair DNA synthesis by DNA polymerase $\varepsilon$ in the presence of PCNA, RFC, and RPA. Biochemistry 34, 5011-5017.

138. Shivji, M.K.K., Ferrari, E., Ball, K., Hübscher, U., and Wood, R.D. (1998) Resistance of human nucleotide excision repair synthesis in vitro to p2 ${ }^{\text {Cdn1 }}$. Oncogene 17, 2827-2838.

139. Araújo, S.J., Tirode, F., Coin, F., Pospiech, H., Syväoja, J.E., Stucki, M., Hübscher, U., Egly, J.-M., and Wood, R.D. (2000) Nucleotide excision repair of DNA with recombinant human proteins: definition of the minimal set of factors, active forms of TFIIH, and modulation by CAK. Genes Dev. 14, 349-359.

140. Wang, Z., Wu, X., and Friedberg, E.C. (1993) DNA repair synthesis during base excision repair in vitro is catalyzed by DNA polymerase epsilon and is influenced by DNA polymerases $\alpha$ and $\delta$ in Saccharomyces cerevisiae. Mol. Cell. Biol. 13, 1051-1058.

141. Wang, Z., Wu, X., and Friedberg, E.C. (1992) Excision repair of DNA in nuclear extracts from the yeast Saccharomyces cerevisiae. Biochemistry 31, 3694-6702.

142. Budd, M.E. and Campbell, J.L. (1995) DNA polymerases required for repair of UV-induced damage in Saccharomyces cerevisiae. Mol. Cell. Biol. 15, 2173-2179.

143. Halas, A., Policińska, Z., Baranowska, H., and Jachymczyk, W.J. (1999) The essential DNA polymerases $\delta$ and $\varepsilon$ are involved in repair of UV-damaged DNA in the yeast Saccharomyces cerevisiae. Acta Biochim. Pol. 46, 289-298.

144. Wu, X., Guo, D., Yuan, F., and Wang, Z. (2000) Accessibility of DNA polymerases to repair synthesis during nucleotide excision repair in yeast cell-free extracts. Nucleic Acids Res. 29, 3123-3130. 
145. Kubota, Y., Nash, R.A., Klungland, A., Schär, P., Barnes, D.E., and Lindahl, T. (1996) Reconstitution of DNA base excision-repair with purified human proteins: interaction between DNA polymerase $\beta$ and the XRCC1 protein. EMBO J. 15, 6662-6670.

146. Klungland, A. and Lindahl, T. (1997) Second pathway for competition of human DNA bases excision repair: reconstitution with purified proteins and requirement for Dnase IV (FEN1). EMBO J. 16, 3341-3348.

147. Nicoll, I.D., Nealon, K., and Kenny, M.K. (1997) Reconstitution of human base excision repair with purified proteins. Biochemistry 36, 7557-7566.

148. Fortini, P., Parlanti, E., Sidorkina, O.M., Laval, J., and Dogliotti, E. (1999) The type of DNA glycosylase determines the base excision repair pathway in mammalian cells. J. Biol. Chem. 274, 15230-15236.

149. Nash, R.A., Caldecott, K., Barnes, D.E., and Lindahl, T. (1997) XRCC1 protein interacts with one of two distinc forms of DNA ligase III. Biochemistry 36, 5207-5211.

150. Cappelli, E., Taylor, R., Cesvasco, M., Abbonandolo, A., Caldecott, K., and Frosina, G. (1997) Involvement of XRCC1 and ligase III gene products in DNA base excision repair. J. Biol. Chem. 272, 23970-23975.

151. Prasad, R., Singhal, R.K., Srivastava, D.K., Molina, J.T., Tomkinson, A.E., and Wilson, S.H. (1996) Specific interaction of DNA polymerase $\beta$ and ligase $I$ in a multiprotein base excision repair complex from bovine testis. J. Biol. Chem. 271, 16000-16007.

152. Frosina, G., Fortini, P., Rossi, O., Carrozzino, F., Raspaglio, G., Cox, L.S., Lane, D.P., Abbondandolo, A., and Dogliotti, E. (1996) Two pathways for base excision repair in mammalian cells. J. Biol. Chem. 271, 95739578.

153. Stucki, M., Pascucci, B., Parlanti, E., Fortini, P., Wilson, S.H., Hübscher, U., and Dogliotti, E. (1998) Mammalian base excision repair by DNA polymerases $\delta$ and $\varepsilon$. Oncogene 17, 835-843.

154. Matsumoto, Y., Kim, K., Hurwitz, J., Gary, R., Levin, D.S., Tomkinson, A.E., and Park, M.S. (1999) Reconstitution of proliferating cell nuclear antigen-dependent repair of apurinic/apyrimidinic sites with purified human proteins. J. Biol. Chem. 274, 33703-33708.

155. Dantzer, F., de La Rubia, G., Menissier-De Murcia, J., Hostomsky, Z., de Murcia, G., and Schreiber, V. (2000) Base excision repair is impaired in mammalian cells lacking poly(ADP-ribose) polymerase-1. Biochemistry 39, 7559-7569.

156. Podlutsky, A.J., Dianova, I.I., Podust, V.N., Bohr, V.A., and Dianov, G.L. (2001) Human DNA polymerase $\beta$ initiates DNA synthesis during long-patch repair of reduced AP sites in DNA. EMBO J. 20, 1477-1482.

157. Prasad, R., Lavrik, O.I., Kim, S.J., Kedar, P., Yang, X.P., Vande Berg, B.J., and Wilson, S.H. (2001) DNA Polymerase $\beta$-mediated long patch base excision repair. Poly(ADP-ribose) polymerase-1 stimulates displacement DNA synthesis. J. Biol. Chem. 276, 32411-32414.

158. Fortini, P., Pascucci, B., Parlanti, E., Sobol, R.W., Wilson, S.H., and Dogliotti, E. (1998) Different DNA polymerases are involved in the short- and long-patch base excision repair in mammalian cells. Biochemistry 37, 3575-3580.

159. Kim, K., Biade, S., and Matsumoto, Y. (1998) Involvement of flap endonuclease 1 in base excision DNA repair. J. Biol. Chem. 273, 8842-8848.

160. Gary, R., Kim, K., Cornelius, H.L., Park, M.S., and Matsumoto, Y. (1999) Proliferating cell nuclear antigen facilitates excision in long-patch base excision repair. J. Biol. Chem. 274, 4354-4363.

161. Jónsson, Z.O. and Hübscher, U. (1997) Proliferating cell nuclear antigen: more than a sliding clamp for DNA polymerases. Bioessays 19, 967-975.

162. Levin, D.S., McKenna, A.E., Motycka, T.A., Matsumoto, Y., and Tomkinson, A.E. (2000) Interaction between PCNA and DNA ligase I is critical for joining of Okazaki fragments and long-patch base-excision repair. Curr. Biol. 10, 919-922.

163. Göttlich, B., Reichenberger, S., Feldmann, E., and Pfeiffer, P. (1998) Rejoining of DNA double-strand breaks in vitro by single-strand annealing. Eur. J. Biochem. 258, 387-395.

164. Pospiech, H., Rytkönen, A.K., and Syväoja, J.E. (2001) The role of DNA polymerase activity in human nonhomologous end joining. Nucleic Acids Res. 29, 3277-3288.

165. Longley, M.J., Pierce, A.J., and Modrich, P. (1997) DNA polymerase $\delta$ is required for human mismatch repair in vitro. J. Biol. Chem. 272, 10917-10921.

166. Xiao, W., Chow, B.L., Broomfield, S., and Hanna, M. (2000) The Saccharomyces cerevisiae RAD6 group is composed of an error-prone and two error-free postreplication repair pathways. Genetics 155, 1633-1641. 
This article should be referenced as follows:

Pospiech, H. and Syväoja, J.E. (2003) DNA Polymerase $\varepsilon$ - More Than a Polymerase. TheScientificWorldJOURNAL 3, 87104.

\section{Handling Editor:}

U. Hubscher, Principal Editor for Enzymology and Protein - Protein Interaction - a domain of TheScientificWorldJOURNAL. 

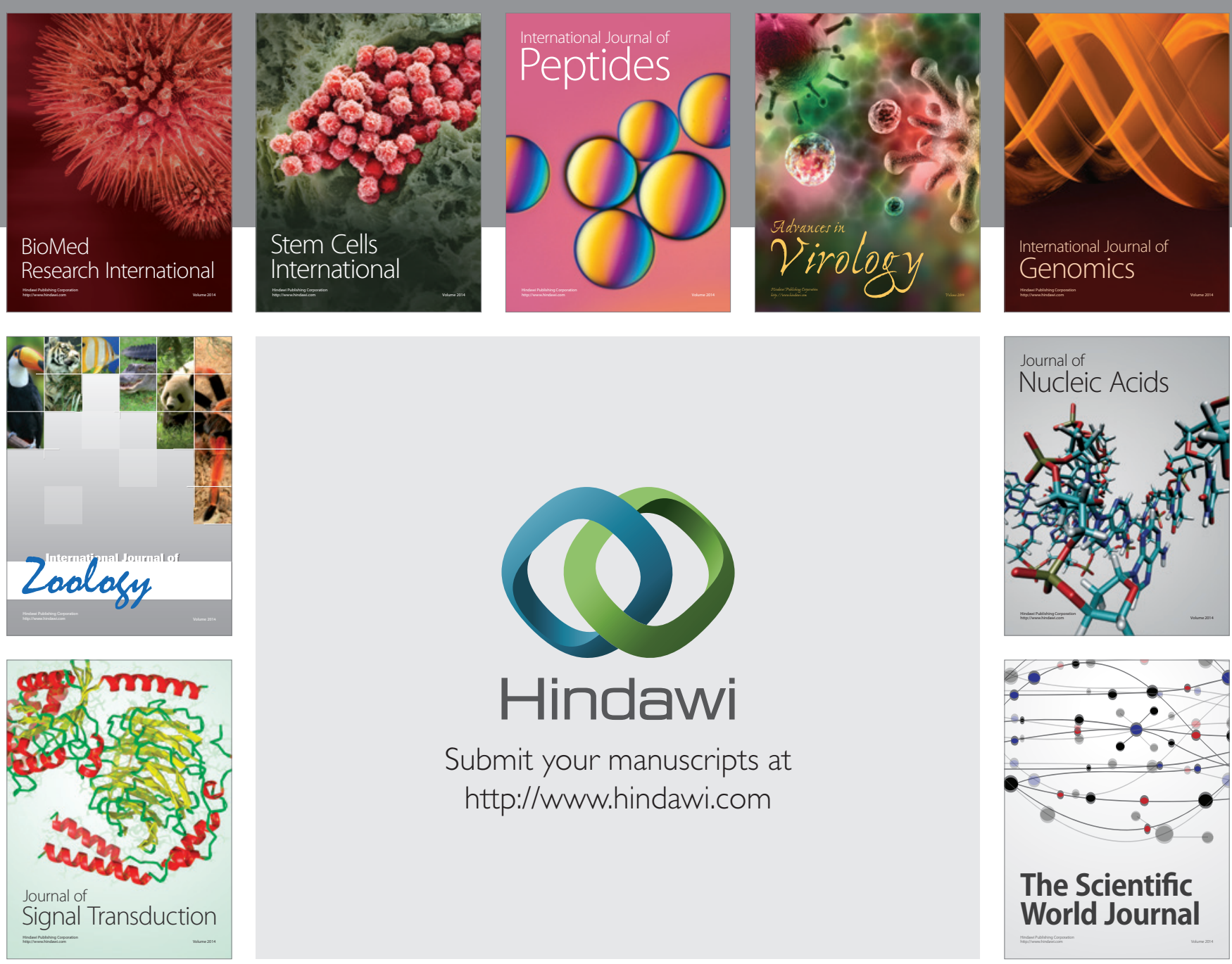

Submit your manuscripts at

http://www.hindawi.com
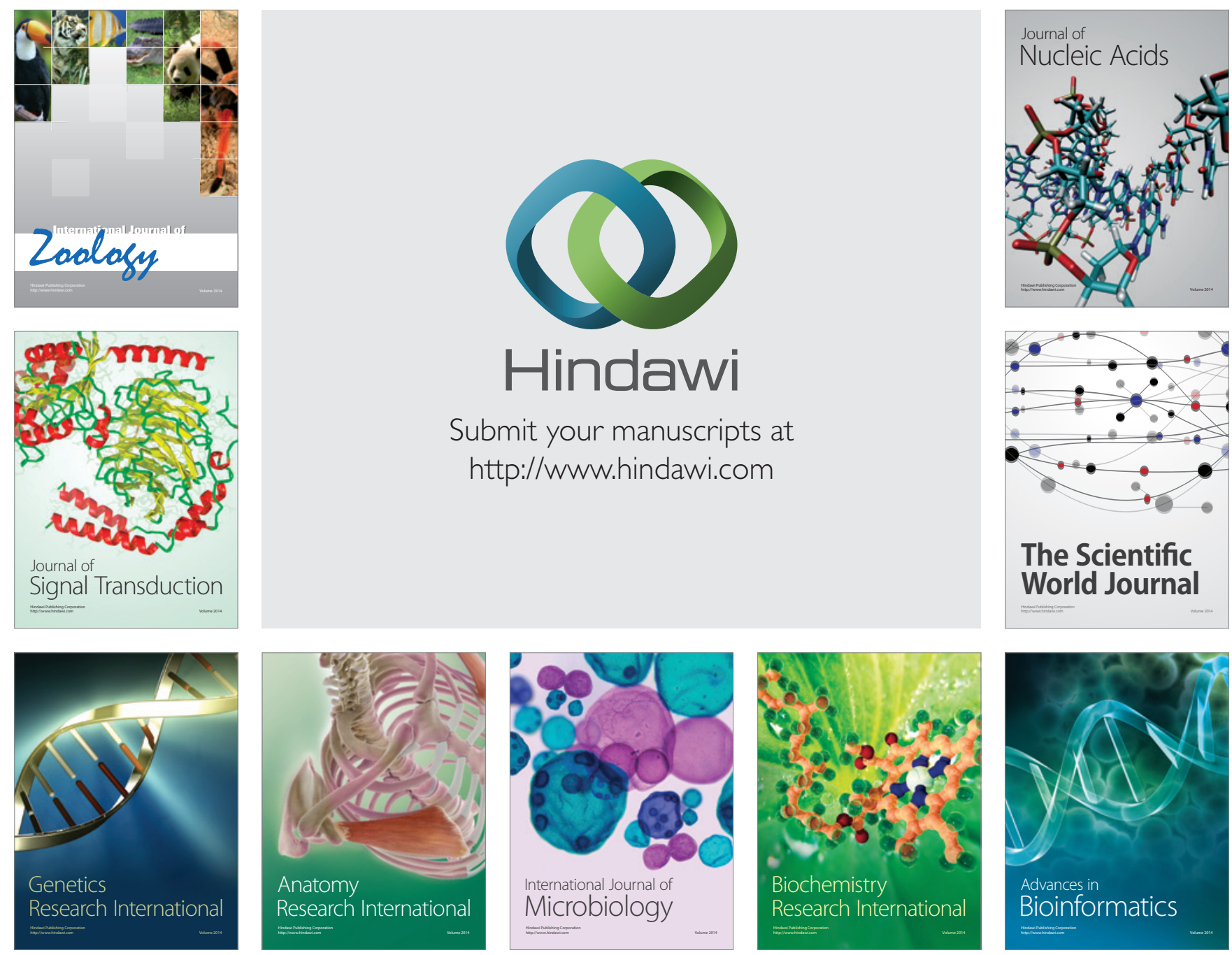

The Scientific World Journal
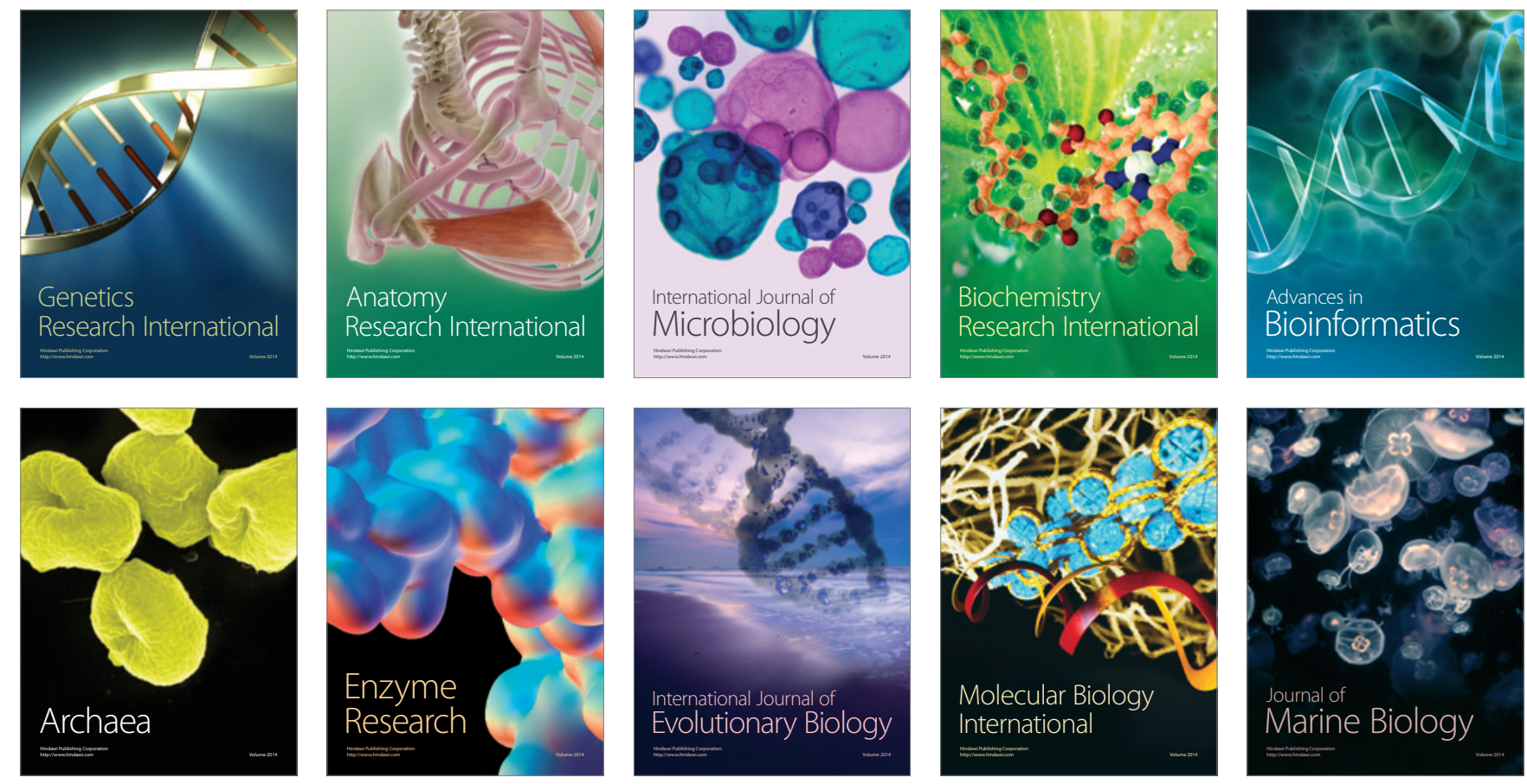